\title{
"cara, cor, corpo" e a constituição do campo de estudos de gênero
}

Iara Beleli*

O documento ora publicado no cadernos pagu, escrito no início dos anos de 1980, me foi mostrado por Mariza Corrêa em 2004. Após ávida leitura, sugeri que o publicássemos como documento na segunda edição do cadernos pagu daquele ano, porque estabelecia uma clara interlocução com o dossiê organizado por Mariza naquele número. A resposta foi taxativa: "NÃO! Quando eu morrer você faz o que quiser com esse texto". Eu já conhecia Mariza o suficiente para saber que ela gostava de ser reconhecida pelos seus feitos, mas abominava a autopromoção, assim como fazia questão de nomear explicitamente a importância das parcerias para realizar projetos.

Um desses projetos, "a menina de seus olhos", era o Núcleo de Estudos de Gênero - Pagu/Unicamp e o cadernos pagu, ambos criados em 1993. No entanto, não permitia, sem forte contestação, que lhe atribuíssem esse feito, marcando o papel fundamental de Adriana Piscitelli, na época sua orientanda de doutorado, na criação e na consolidação do núcleo e da revista; atualmente, Adriana é uma pesquisadora reconhecida nacional $e$ internacionalmente, e fez com que a produção do Pagu atravessasse fronteiras. Mariza tinha um feeling para suas apostas!

Esse preâmbulo é fundamental para falar do documento escrito por Mariza, porque ela ensaia, dez anos antes, ideias que se tornaram centrais na consolidação dos estudos de gênero no Brasil e do Pagu. O subtítulo - "especulação sobre a intuição feminina" - é tão importante quanto o título - "Cara, Cor, Corpo" - porque faz perguntas sobre o lugar de determinados temas na ciência,

* Pesquisadora do Núcleo de Estudos de Gênero-Pagu, Unicamp, Campinas, SP, Brasil. iarabeleli@gmail.com 
"especulando" sobre o que é ou não considerado ciência. Para isso, Mariza se volta para exemplos da vida miúda das pessoas, destacando o emaranhado de elementos que constituem, afinal, as relações de poder.

Mariza aponta para questões/indagações/assertivas pautadas por duas ideias centrais: universalidade da diferença e o sexo biológico como base para essa diferença. Como antropóloga, Mariza nunca aceitaria a "universalidade", vide sua crítica (1999) à La domination masculine, de Pierre Bourdieu (1998), autor pelo qual ela tinha muito apreço. Mariza também era uma contestadora contumaz da ideia de que tanto o sexo quanto a "raça" pudessem servir de base para a produção de diferença. Essa contestação, que aparece em várias de suas produções científicas posteriores, são ensaiadas no documento inédito aqui publicado, escrito em um momento em que autoras de diferentes regiões do mundo começavam a escrever sobre as questões de gênero.

Esses trabalhos, publicados entre 1988 e 1990, marcaram a constituição do campo de estudos de gênero a partir de diferentes disciplinas: a antropóloga Marylin Strathern (1988), a historiadora Joan Scott (1988) e a filósofa Judith Butler (1990). Não me consta que Mariza tivesse uma interlocução mais estreita com essas autoras no momento em que escrevia o texto aqui publicado como documento (1980), até porque elas não são citadas nas referências bibliográficas, o que me leva a pensar que estava sendo gestado no Brasil, pelas mãos de Mariza, um conhecimento sobre gênero, ainda que ela não o nomeasse dessa forma, em sincronicidade com as ideias gestadas pelo mundo afora.

As reflexões de Mariza certamente estavam informadas por sua trajetória feminista, que mais tarde influenciou tanto seu percurso na antropologia, como o "passar adiante" esse saber para alunas e alunos, instigando-os a prestar atenção àquilo que parece não ter importância para a produção de conhecimento, mas que pode ser fundamental para criar imaginações sobre o "outro". Não por acaso, Adriana Piscitelli faz a resenha do livro original de Marilyn Strathern (1988) em 1994, que viria a ser 
publicado no Brasil mais de 20 anos depois. ${ }^{1}$ Vale mencionar ainda a resenha de Karla Bessa de Gender Trouble (Judith Butler) publicada em 1995 e traduzida em $2003 .^{2}$

Há quase 40 anos, um documento histórico, escrito por uma antropóloga feminista em um contexto que anunciava ventos de liberdade de pensamento e profícuo no avanço do conhecimento no que remete aos direitos, ganha atualidade. Voltamos no tempo $e$, seguramente, teremos que explicar com muita paciência, como fez Mariza, como esse debate nos constitui enquanto sujeitos, explicar que esses "outros" marcados por diferenças - classe, sexo, gênero, sexualidade, raça/etnia, geração, nacionalidade, localização, religião etc. - somos nós! Esse trabalho pode ser mais árduo do que permite a nossa imaginação, dado que em meados dos anos de 1980 mal saíamos de um regime autoritário; neste final da segunda década do século XXI estamos apenas experimentando o início de tempos obscuros e sombrios.

\section{Referências bibliográficas}

BESSA, Karla Adriana Martins. "Gender Trouble": outra perspectiva de compreensão do Gênero. cadernos pagu (4), Campinas, SP, Núcleo de Estudos de Gênero - Pagu/Unicamp, 1995, pp.261-267.

BouRdieu, Pierre. La domination masculine. Paris, Seuil, 1998.

BUTLER, Judith. Gender Trouble: feminism and the subversion of identity. New York, Routledge/Champman \& Hall, 1990 [Problemas de gênero: feminismo e subversão da identidade. Rio de Janeiro, Editora Civilização Brasileira, 2003. Tradução: Renato Aguiar].

CORRÊA, Mariza. O sexo da dominação. Novos Estudos CEBRAP n 54 , São Paulo, julho 1999, pp.43-53.

1 Testemunhei os esforços de Adriana Piscitelli e Mariza Corrêa junto à Editora da Unicamp para que o livro de Strathern fosse traduzido.

2 As resenhas foram publicadas nas primeiras edições do cadernos pagu e, certamente, alavancaram o espraiamento das ideias das autoras, estimulando a leitura desses livros entre professoras/es e alunas/os. 
PISCITELli, Adriana. Resenha The Gender of the Gift. cadernos pagu (2), Campinas, SP, Núcleo de Estudos de Gênero Pagu/Unicamp, 1994, pp.211-219.

ScOTT, Joan Wallach. Gender and the Politics of History. New York, Columbia University Press, 1988.

Gênero: uma categoria de análise histórica. Educação \& Realidade (20):2, jul/dez. 1995, pp.71-99.

STRATHERn, Marilyn. The Gender of the Gift : Problems With Women and Problems With Society in Melanesia Studies in Melanesian. California, University of California Press, 1988 [ O gênero da Dádiva Problemas com as mulheres e problemas com a sociedade na Melanésia. Campinas-SP, Editora da Unicamp, 2013. Tradução: André Villalobos]. 